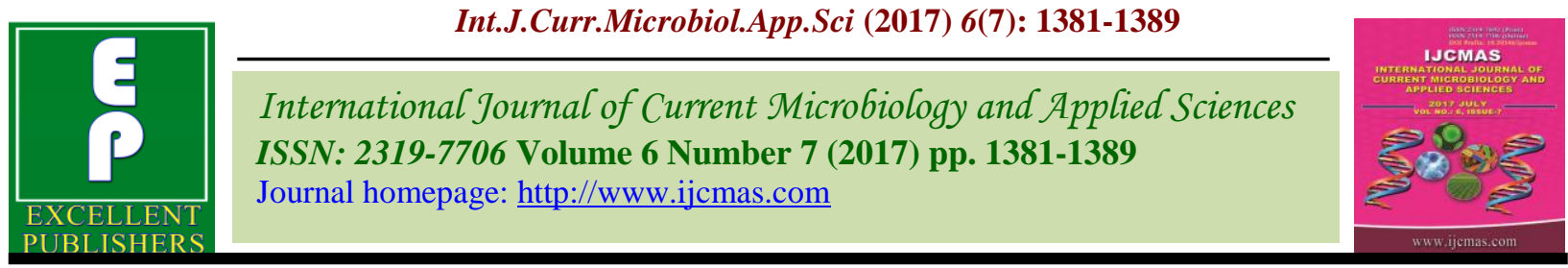

Original Research Article

https://doi.org/10.20546/ijcmas.2017.607.165

\title{
Studies on Preparation and Nutritional Quality of Sorghum-Fingermillet Chakli
}

\author{
S.D. Patekar*, D.R. More and P.N. Satwadhar \\ Department of Food trade and Business Management, College of Food Technology, \\ Vasantarao Naik Marathwada Krishi Vidyapeeth, Parbhani-431 402, (M.S.), India \\ *Corresponding author
}

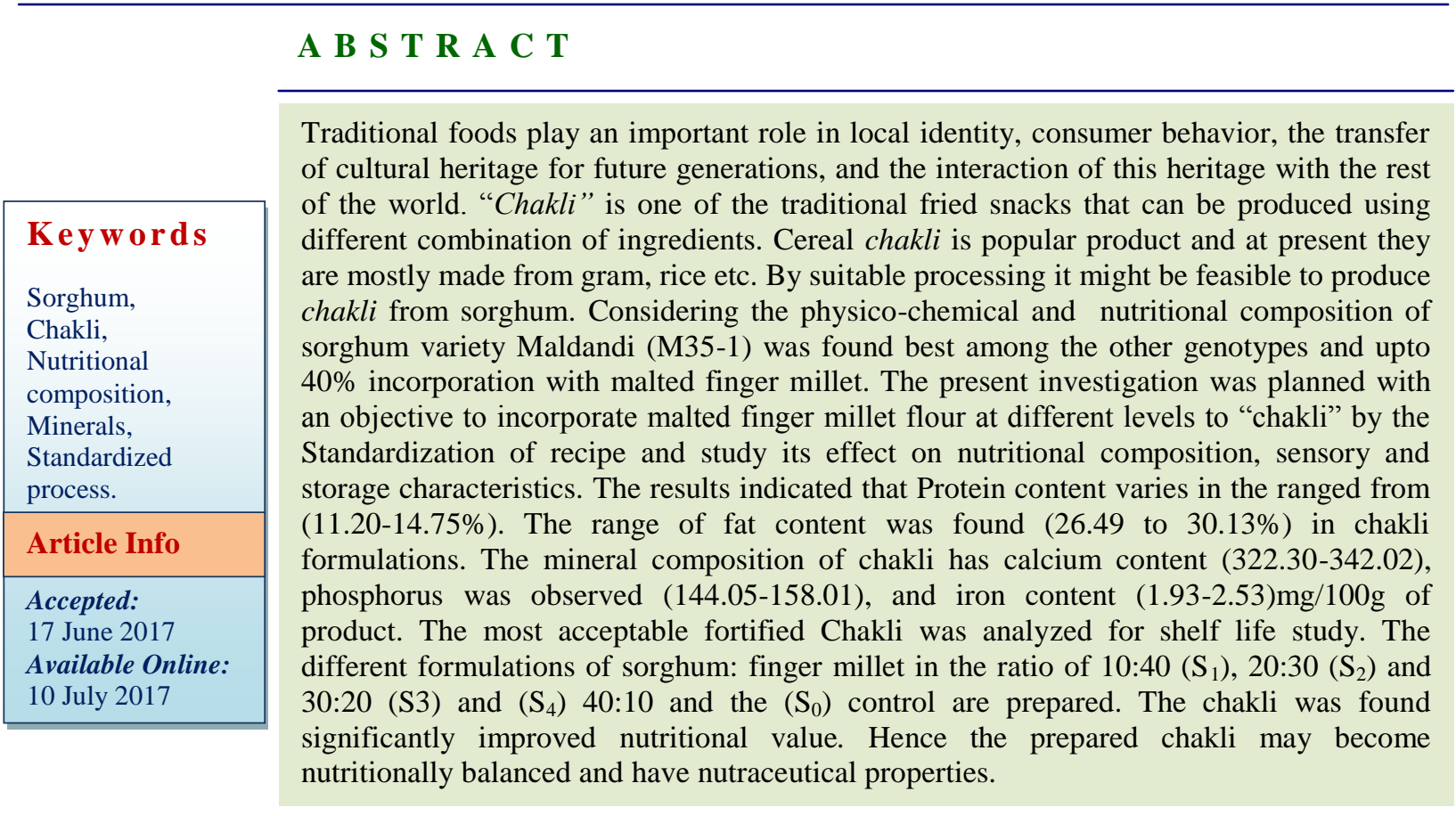

\section{Introduction}

Cereal grains are the most important source of the world's food and have a significant role in the human diet throughout the world. Sorghum (Sorghum bicolor L.) is one of the major cereal crop consumed in India after rice (Oryza sativa L.) and wheat (Triticum aestivium $L$.). Sorghum is commonly called as jowar or great millet. The crop is primarily produced in Maharashtra and Southern states like Karnataka and Andhra Pradesh. Sorghum has 11.9 per cent of moisture and about 10.4 per cent of protein and a lower fat content of 1.9 per cent. The fibre and mineral content of grain sorghum is around 2.1 per cent and 1.6 per cent respectively. It is a good source of energy and provides about $349 \mathrm{~K} \mathrm{cal} / 100 \mathrm{~g}$ and gives 72.6 per cent of carbohydrates (Gopalan et al., 1996). Sorghum does not have gluten and hence becomes a very good ideal gluten free energy source for the people suffering from wheat or gluten allergies. 
Besides sorghum, other millets also have good nutritional value. In ancient India, finger millet (ragi) (Eleusine coracana) was a well domesticated plant in various states. It was traditionally referred as nachni (meaning dancer) in Maharashtra, umi in Bihar, etc. (Achaya 2009). Finger millet contains about 5-8 \% protein, 1-2 \% either extractives, 65$75 \%$ carbohydrates, $15-20 \%$ dietary fiber and 2.5-3.5\% minerals (Chethan and Malleshi, 2007). It has the highest Calcium content among all cereals $(344 \mathrm{mg} / 100 \mathrm{~g}$ ), contains phosphorous $283 \mathrm{mg} / 100 \mathrm{~g}$ and Iron $3.9 \mathrm{mg} / 100 \mathrm{~g}$. Traditionally ragi is processed either by malting or fermentation (Rao et al., 2001). Malting of finger millet improves its digestibility, sensory and nutritional quality as well as pronounced effect in the lowering the antinutrients. Malting characteristics of finger millet are superior to other millets and ranks next to barley malt (Pawar et al., 2007) (Table 4).

In India, a number of snack food items are prepared from a different raw materials like besan (Bengal gram flour), maida (refined wheat flour), urad (black gram) dhal, moong (green gram) dhal, alone or in combination with other cereals and legumes/ pulses. "Chakli" is a common term for a variety of fried snacks that can be made using different combination of ingredients. Ready to eat products like chakali is very popular being crisp and friable in texture. The relatively smaller size and quick hydration of millets make them most suitable for the production of chakali (Chavan et al., 2016).

The present investigation was planned with an objective to incorporate malted finger millet flour at different levels to "chakli" and study its effect on nutritional composition, sensory and storage parameters. The variation in commercial chakli for nutrients and sensory attributes needs attention for Optimization of the product for sustainable quality
(Geethalaxmi and Prakash, 2000). In view of above information regarding the nutritive status and therapeutic importance of sorghum along with other millet, the present work have been undertaken to formulate and evaluate the qualities of sorghum-finger millet chakli. The chakli made up of sorghum flour mixing with malted finger millet flour and pulses flour was significantly improved nutritional value in terms of total protein and minerals content (calcium, iron, phosphorus and zinc) compared to unfortified chakli.

\section{Materials and Methods}

\section{Raw materials}

Good quality raw materials sorghum (Sorghum bicolor) Rabi cultivar like M351(Maldandi), CSV-22R, Parbhani jyoti, varieties were procured from Sorghum Research Station Parbhani, Maharashtra. Finger millet, rice and pulses like Bengal gram, green gram, black gram procured from local market of parbhani and university farmers field V.N.M.K.V, Parbhani.

\section{Chemicals and processing equipments}

Chemicals used in this investigation were of analytical grade. The equipment's and machineries required in the present investigation were used from Department of Food trade and business management, Department of Food Chemistry and Nutrition, Department of Food Science and Technology, College of Food Technology, VNMKV Parbhani. Figure 1 explains the process of sorghum-finger millet chakli

\section{Methods}

\section{Physical characteristics of developed chakli}

The average weight of uniform size chakli was selected for study. The average diameter 
of chakli was reported in mm. (AACC, 1967). For the density of chakli difference in volume was calculated and expressed in $\mathrm{g} / \mathrm{cm} 3$ as density. The determination of water and oil absorption of chakli will be determined according to the method described by Rosario and Flores (1981).

\section{Proximate composition of sorghum-finger millet chakli}

The proximate composition of chakli samples were determined using standard methods. The protein, fat and crude fiber was determined by the method as described in AOAC (1992). Total carbohydrate was determined by standard procedure using phenol and sulphuric acid AOAC (1990). Mineral contents of different chakli mix were obtained by calculation using table value (Gopalan et al., 1996).

\section{Texture profile analysis of sorghum-finger millet chakli}

Stable Micro System TAXT2 plus Texture Analyser was used for texture profile analysis (TPA) of Chakli. Texture Profile Analysis (TPA) of Sorghum-finger millet Chakli was determined with the texture analyzer using double compression tests by using circular probe of $70 \mathrm{~mm}$ of diameter. Chakli were prepared by moderately substituting rice flour with $(10,20,30,40 \%)$ sorghum flour and finger millet malt flour (FMM). The percent escalation in substitution was done till they were acceptable and the Chakli can be easily fried without breakage. Recipe of the standardized Chakli was given in table 1 .

\section{Standardization of process for sorghum- finger millet chakli}

Recipe of the standardized Chakli was as follows Sorghum-malted finger millet flours $(50 \%)$, rice flour mixture $(20 \%)$, washed Bengal gram, green gram, black gram pulse
(30\%) and fat $(50 \%)$. Preparation was as follows firstly, cereal + pulse mixture (Sorghum-finger millet flour, rice flour, Bengal, green, black gram), Salt, cumin seeds, oil and asafoetida were mixed to develop a firm dough using warm water simultaneously. The dough was allowed to rest for some time after that dough is filled in the Chakli presser and Chakli were shaped and simultaneously fried in hot oil on slow flame. After frying and Chakli were allowed to cool down and kept in air tight containers for further analysis (Table 2).

\section{Sensory and organoleptic evaluation of} developed product

The sensory quality characteristics of the developed products such as colour, taste, texture, flavor and overall acceptability were evaluated by panel of judges using nine point hedonic scale as described by Amerine et al., (1965). According to sensory score card evaluation the best sample was chosen for the further study.

\section{Storage studies}

The storage stability of sorghum-finger millet chakli finalized in sensory studies along with control) were carried out using aluminium foil, polypropylene, low density polyethylene (LDPE) pouches for a period of 1 month at ambient conditions. All samples were drawn periodically after 0,15 , and 30 days analyzed for sensory qualities.

\section{Statistical analysis}

All processing equipment's and analysis of samples were run in triplicate. Analysis of variance was calculated using standard ANOVA procedure. The recorded data statistically analyzed by complete randomized design (CRD) to find out the level of significance as per the method proposed by Panse and Sukhatme (1967). The standard 
error (SE) and critical difference (CD) at $5 \%$ level were mentioned where required.

\section{Results and Discussion}

Proximate composition of sorghum and finger millet grains

The protein content in sorghum grain ranged from $10.39 \%$ to $10.49 \%$. The genotype Maldandi gave a significantly higher level of protein $(10.49 \%)$ in the grain and followed by $(10.42 \%)$ in CSV-22R. the results revealed that the genotype Parbhani Jyoti content the higher level of fat $(1.80 \%)$ followed by Maldandi $(1.68 \%)$ whereas lower level of fat was reported in CSV-22R cultivar that was $(1.55 \%)$. it is observed that the total carbohydrate content in the maldandi (M-35-
1) was highest whereas the lowest carbohydrate content of $71.01 \%$ in Yparbhani Jyoti was reported by Chavan et al., (2009), Butti Prabhakar et al., (2016).

The moisture content reported in finger millet was $(11.60 \%)$. protein content of finger millet recorded was $(7.52 \%)$. The carbohydrate recorded that was $(73.30 \%)$. Pragya and Rita (2012) reported the total carbohydrate content of finger millet was ranged between 72 to 79.5 per cent. It was observed that $(3.21 \%)$ crude fiber. Similar results about chemical composition of finger millet were found by Desai et al., (2010). The prepared Chakli were subjected to Nutritional content and the data pertaining to this evaluation of Chakli along with control Chakli are summarized in table 3 .

Table.1 Basic recipe for making sorghum-finger millet chakli

\begin{tabular}{ll}
\hline Ingredients & Quantity $(\mathbf{g})$ \\
\hline Sorghum flour & 20 \\
Malted Finger millet flour & 30 \\
Rice flour & 20 \\
Pulses mixture & 30 \\
Chilli powder & 3 \\
Cumin seed & 5 \\
Turmeric & 2 \\
Salt & 2 \\
Hot water (ml) & 100 \\
Oil (for frying) & 200 \\
\hline
\end{tabular}

Table.2 Optimization of processing parameters for chakli

\begin{tabular}{ll}
\hline Process parameter & Value \\
\hline Initial temperature of oil & $180^{\circ} \mathrm{C}$ \\
Final temperature for frying & $160^{\circ} \mathrm{C}$ \\
Time taken for frying & $2-3 \mathrm{Min}$ \\
Resting period of Dough & $15 \mathrm{Min}$ \\
\hline
\end{tabular}


Table.3 Nutritional composition of sorghum-finger millet chakli

\begin{tabular}{lllllll}
\hline Sample code & Moisture & Fat & Protein & Carbohydrate & Crude fiber & Ash \\
\hline $\mathrm{S}_{0}($ Control $)$ & 2.8 & 28.91 & 11.20 & 50.58 & 3.32 & 3.19 \\
$\mathrm{~S}_{1}$ & 3.0 & 30.13 & 14.42 & 46.45 & 3.54 & 2.46 \\
$\mathrm{~S}_{2}$ & 2.1 & 26.49 & 14.75 & 50.61 & 3.45 & 2.6 \\
$\mathrm{~S}_{3}$ & 2.3 & 26.95 & 13.87 & 50.49 & 3.49 & 2.90 \\
$\mathrm{~S}_{4}$ & 2.8 & 29.26 & 13.64 & 47.45 & 3.75 & 3.10 \\
\hline Mean & 2.60 & 2.83 & 1.35 & 4.91 & 3.51 & 2.85 \\
$\mathrm{SE} \pm$ & 0.0577 & 0.0057 & 0.0165 & 0.0064 & 0.0057 & 0.0263 \\
$\mathrm{CD}$ at $5 \%$ & 0.1816 & 0.0181 & 0.0520 & 0.0204 & 0.0181 & 0.0828 \\
\hline
\end{tabular}

*Each value is a mean of three determinations

Fig.1 Preparation of sorghum-finger millet chakli

\section{Technology for preparation of sorghum-finger millet chakli}

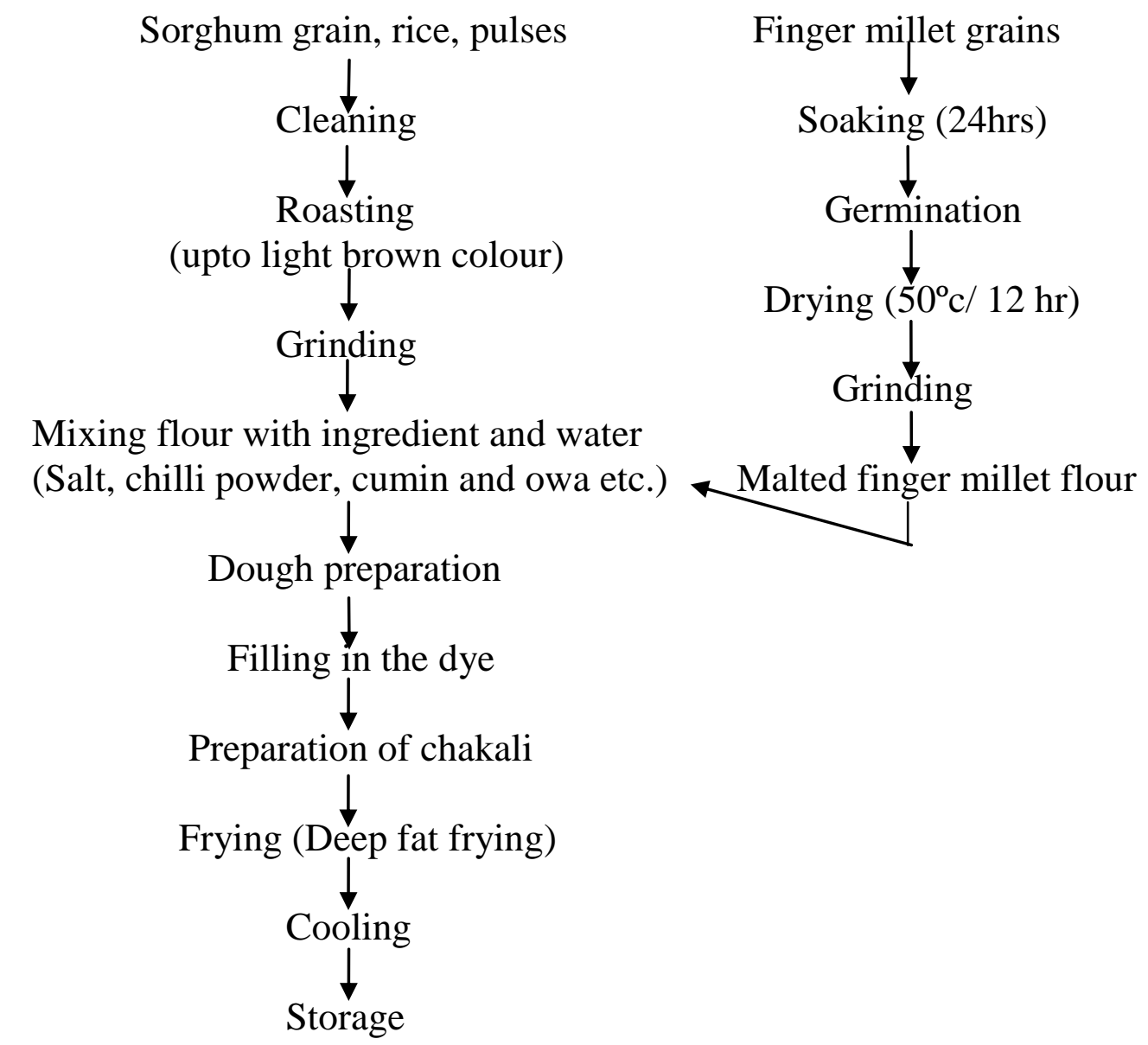


Graph.1 Sensory evaluation of sorghum-finger millet chakli

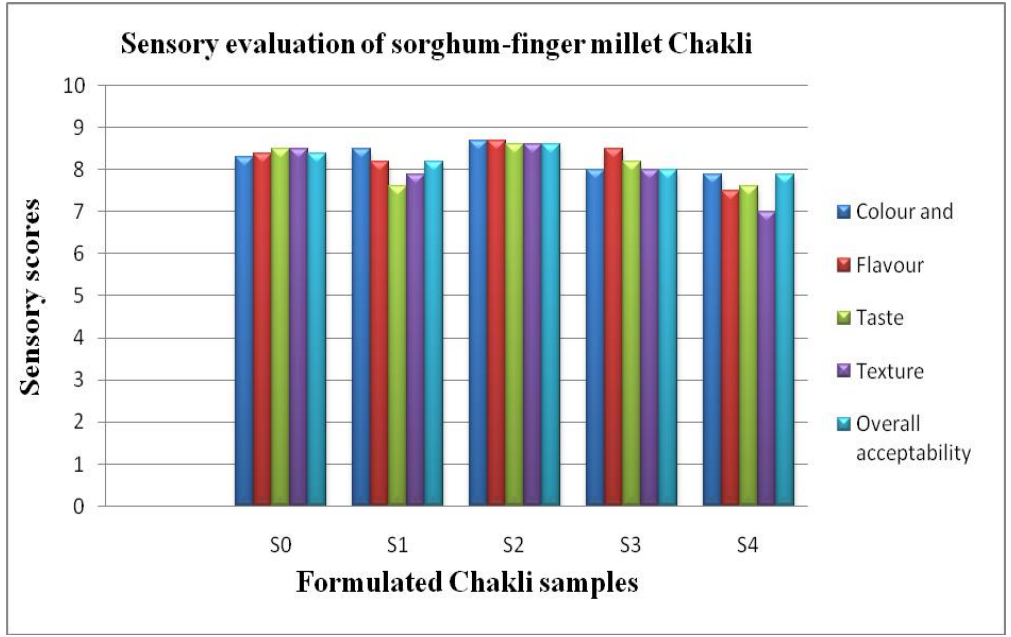

Graph.2 Hardness characteristics of sorghum-finger millet chakli

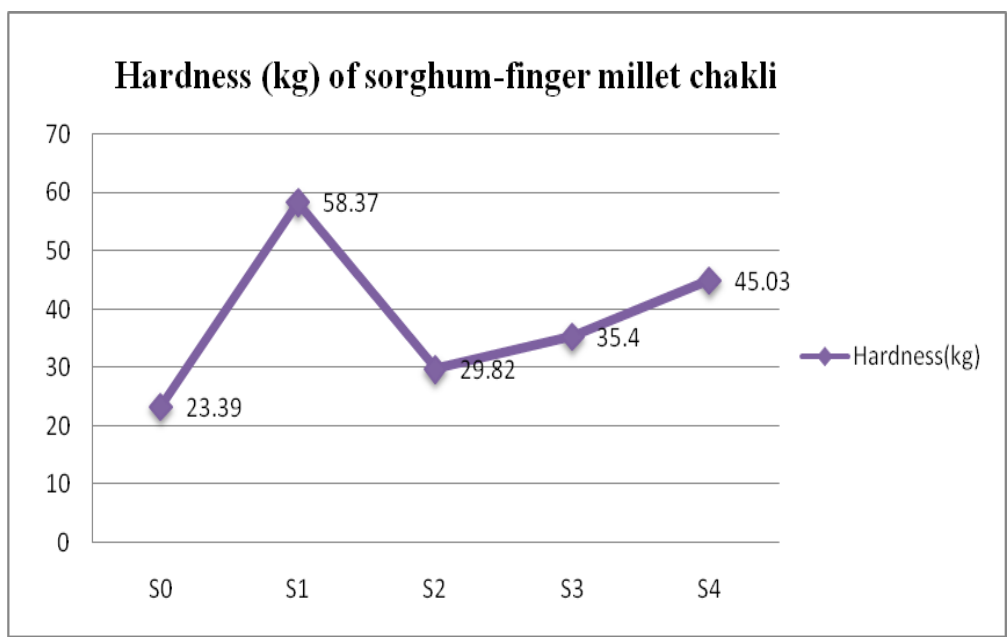

Table.4 Mineral composition of sorghum-finger millet chakli

\begin{tabular}{cccc}
\hline Sample code & \multicolumn{3}{c}{ Mineral composition of Chakli (mg/100gm) } \\
\cline { 2 - 4 } & Calcium & Phosphorus & Iron \\
$\mathrm{S}_{0 \text { (CONTROL) }}$ & 285.01 & 56.03 & 1.45 \\
$\mathrm{~S}_{1}$ & 342.02 & 144.05 & 1.93 \\
$\mathrm{~S}_{2}$ & 335.60 & 148.06 & 2.1 \\
$\mathrm{~S}_{3}$ & 329.20 & 152.03 & 2.33 \\
$\mathrm{~S}_{4}$ & 322.30 & 158.01 & 2.53 \\
\hline Mean & 322.83 & 131.64 & 2.06 \\
$\mathrm{SE} \pm$ & 0.0057 & 0.0057 & 0.0263 \\
$\mathrm{CD}$ at 5\% & 0.0181 & 0.0181 & 0.0828 \\
\hline
\end{tabular}

* Each value is a mean of three determinations 
Table.5 Techno economic feasibility of sorghum-finger millet chakli

\begin{tabular}{llll}
\hline Particulars & Rate $($ Rs/kg) & Quantity (g) & Cost (Rs.) \\
\hline Sorghum & 28 & 500 & 14 \\
Finger millet & 48 & 500 & 24 \\
Rice & 30 & 125 & 3.75 \\
Green gram & 60 & 125 & 7.5 \\
Black gram & 65 & 125 & 8.125 \\
Oil & 90 & 500 & 45 \\
Salt, chilli powder, cumi, owa & - & - & 12 \\
Labour charges & 30 & - & 30 \\
Fuel and packaging & 20 & - & 20 \\
miscellaneous & & & \\
Total yield (kg) & - & $1.6 \mathrm{~kg}$ & Rs.164.37 \\
Cost /kg (chakli) & - & $1 \mathrm{~kg}$ & $=102.5$ \\
\hline
\end{tabular}

Plate.1 Formulated samples of sorghum-finger millet chakli
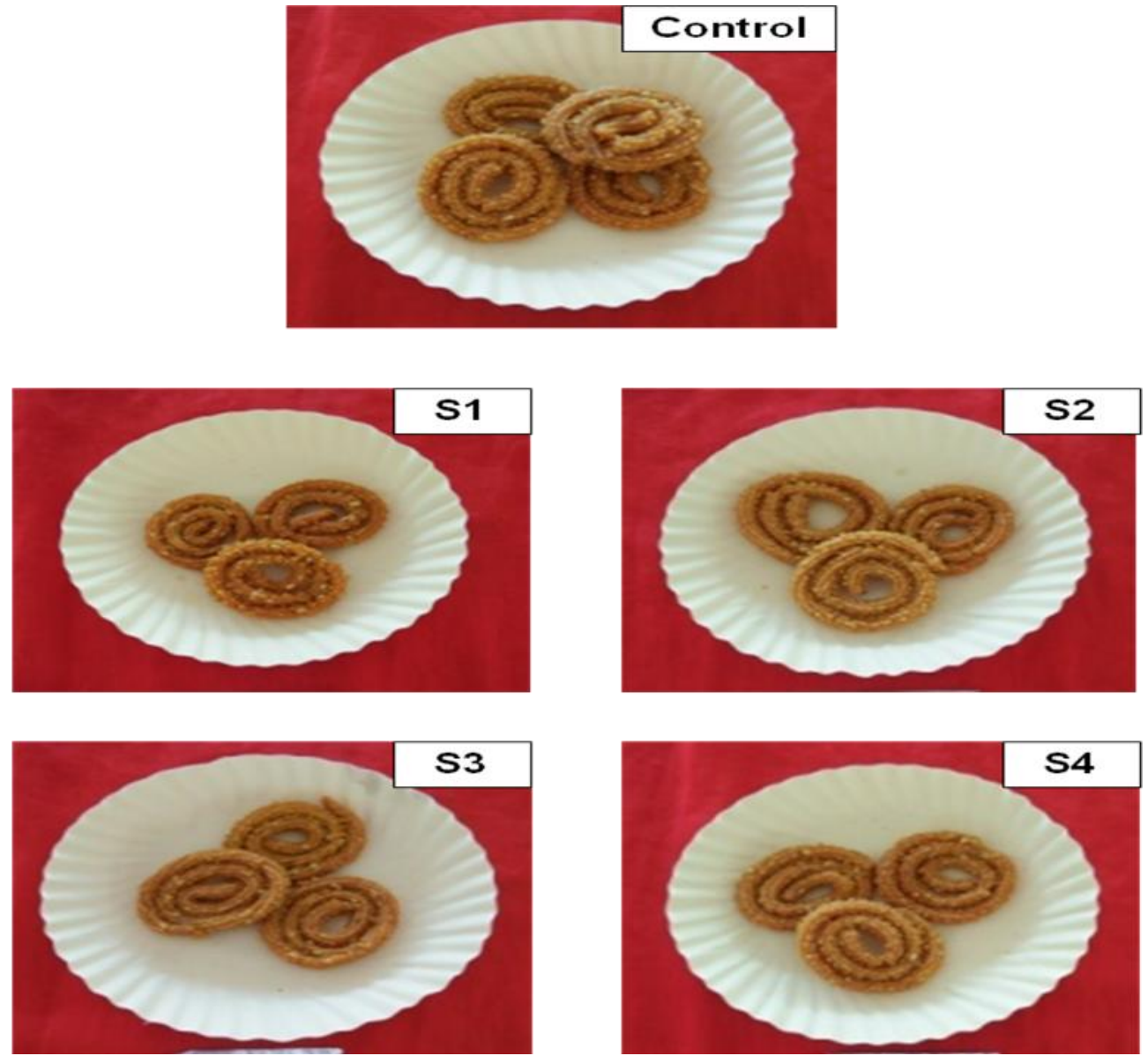
Results given in table 3 revealed that moisture content significantly varied from (2.1 to $3.0 \%)$. The range of fat content was found to be (26.49 to 30.13 ) percent in various chakli whereas the fat content of Control chakli was $(28.91 \%)$. The Protein content of prepared Chakli varies in the ranged from (11.20-14.75\%). The sample $\left(\mathrm{S}_{2}\right)$ contains maximum protein content $(14.75 \%)$ and it was numerically superior to other formulations. Proximate compositions for the rice chakli were observed by Hoitinkim singson et al., (2014). The Carbohydrate content present in the all Chakli samples were ranged from (46.45\%-50.61\%). the crude fiber content of formulated chakli ranged was (3.32-3.75\%) reported. the ash content of the standardized chakli was ranged from (2.46-3.19\%).the results were comparable with values reported by Sunita et al., (1995); Chavan et al., (2016). An appraisal of table presented that the original control chakli and its modification varied significantly from each other in respect to all the macro and micro nutrients studied.

Calcium, Iron and Phosphorous are of nutritional importance in the diets of population. Calcium content in Control chakli sample $\left(\mathrm{S}_{0}\right)$ was $(285.01 \mathrm{mg} / 100 \mathrm{~g})$ whereas Sorghum-finger millet Chakli sample $\left(S_{1}\right)$ had highest $(342.02 \mathrm{mg} / 100 \mathrm{~g})$ Calcium content. The lowest calcium content was observed in sample $\left(\mathrm{S}_{4}\right)$ that was $(322.30 \mathrm{mg} / 100 \mathrm{~g})$. The phosphorus content of various chakli samples ranged from (144.05-158.01mg/100g).

The control samples had $(1.45 \mathrm{mg} / 100 \mathrm{~g})$ of iron content whereas the higher level of iron content was recorded in the sample $\left(\mathrm{S}_{4}\right)$ that was $(2.53 \mathrm{mg} / 100 \mathrm{~g})$. On the basis of sensory score obtained to all four formulations the sample $\left(S_{2}\right)$ has got the highest score (8.7) for colour and appearance as compare to control. The colour and appearance characteristics of Chakli score ranged from (7.9 to 8.7). The flavor scored for Chakli ranged from (7.5 to 8.7). The significantly highest flavor score was observed for $\left(S_{2}\right)$ that was (8.7). The significantly highest taste score for $\left(S_{2}\right)$ observed was (8.6). The lowest and similar score for the Taste in Sample
$\left(\mathrm{S}_{4}\right)$ and $(\mathrm{S} 1)$ was observed that was (7.6). The mean texture score of all Chakli ranged from (7.0 to 8.6$)$.

The overall acceptability score for Chakli prepared from sorghum-finger millet ranged from (7.9 to 8.6). The overall acceptability score was the highest for $\left(S_{2}\right)$ that was (8.6) followed by $\left(\mathrm{S}_{1}\right)$ (8.2), and lowest score was in Sample $\left(\mathrm{S}_{4}\right)$ that was (7.9). Chavan et al., (2016) reported nutritional and organoleptic quality of sorghum Chakli.

\section{Texture profile analysis of sorghum-finger millet chakli}

Texture profile analysis is a very useful technique for examining the food products however, texture of any product plays very important role in determining the acceptability. Texture Profile Analysis (TPA) of Sorghumfinger millet Chakli was determined with the texture analyzer using double compression tests.

The results of texture profile analysis showed that the peak force required breaking Chakli strand was in between (23.39 to58.37) kg recorded for the samples. The highest value of hardness was recorded in the chakli sample $\left(S_{1}\right)$ with the maximum peak force of $(58.37 \mathrm{~kg})$, while sample $\left(\mathrm{S}_{2}\right)$ has lowest peak force $(29.82 \mathrm{~kg})$ indicating the softer and more fracturable texture. The hardness value of the control $\left(\mathrm{S}_{0}\right)$ sample was very less as compare to the other samples. The peak force required to break chakli sample $\left(\mathrm{S}_{4}\right)$ was increased (45.03) due to higher level of moisture content. The obtained values of hardness recorded in the present study were similar and comparable with the findings of Sawant et al., (2013).

The estimation of cost of production was done by using standard calculation method. By considering the raw material cost, processing cost (20\% of raw material cost) and packaging cost. From table 5 the total production cost of $1.6 \mathrm{~kg}$ product was Rs.164.37 and the total cost for $1 \mathrm{~kg}$ of sorghum-finger millet chakli sample was Rs.102.5. 


\section{References}

Achaya, K.T. 2009. The illustrated foods of India: A-Z. Oxford University Press.

A.A.C.C. 1967. Approved methods of American cereal chemists cereal laboratory methods St. Paul. Minnesots USA.

A.O.A.C. 1990. Official Methods of Analysis. Ternds Food Science Technology. Association of Official Analytical Chemists, Washington DC, USA.

A.O.A.C. 1992. Official methods of analysis 16 edition. Assoc. of official Analytical Chem. Inc., Arlington, VA.

Amerine, M.A., Pangborn, R.M. and Rossler, E.B. 1965. Principles of sensory evaluation of foods. Academic Press, New York. pp. 350-376.

Butti Prabhakar, Mallesh Sanganamoni, Shivashankar, S. and Nagendra Babu, G. 2016. Studies on physico-chemical analysis of sorghum varieties. Int. J. Agri. Sci. Res., 6(1): 87-92.

Chavan, U.D., Patil, J.V. and Shinde, M.S. 2009. Nutritional and Roti quality of sorghum genotypes. Indonesian J. Agri. Sci., 10(2): 80-87.

Chavan, U.D., Jagtap, Y.K., Shinde, M.S. and Patil, J.V. 2016. Preparation and nutritional quality of sorghum Chakli. Int. J. Recent Scientific Res., 7(1): 8404-8411.

Chethan, S. and Malleshi. 2007. Polyphenols: Optimization of extraction and the effect of $\mathrm{pH}$ on their stability. Food Chem., 105(2): 862-870.

Desai, A.D., Kulkarni, S.S., Sahoo, A.K., Ranveer, R.C. and Dandge, P.B. 2010. Effect of supplementation of malted ragi flour on the nutritional and sensorial quality characteristics of cake. $A d v . J$. Food Sci. Technol., 2(1): 67-71.
Geethalakshmi and Jamuna Prakash. 2000. Processing variables and quality Parameters of chakli-an Indian traditional deep fried product. J. Food Sci. Technol., 37: 227-232.

Gopalan, C., Ramasastri, B.V. and Balasubramaniam, S.C. 1996. Nutritive value of Indian foods. National institute of nutrition, Indian Council of Medical Research, Hyderabad, India.

Hoitinkim, S., Shradha, G.S. and Mirmala, B. and Yenagi, S.T. 2014. Documentation of chakali recipies and evaluation of commercial chakali for physic- chemical and sensory attributes. J. Agri. Sci., 27(2): 208-212.

Pawar, P.A. and V.P. Dhanvijay. 2007. Weaning foods: An overview. Beverage Food World, 34(11): 27-33.

Panse, V.S. and Sukhatme, P.V. 1984. Statistical Methods for Agricultural Workers. Indian Council of Agricultural Research. New Delhi, India, 70-72.

Pragya, S. and Rita, S.R. 2012. Finger millet for food and nutritional security. African $J$. Food Sci., 6(4): 77-84.

Rao Subba, M. V. S. S. T. and Muralikrishna, G. 2001. Non-starch polysaccharides and bound phenolic acids from native and malted finger millet (Ragi, Eleusine coracana, Indaf-15. Food Chem., 72(2): 187-192.

Rosario, R.D. and Flores, D.M. 1981. Functional properties of flour types on mung bean flours. J. Sci. Food and Agri., 32: $172-180$.

Sawant, A.A., Thakor, N.J., Swami, S.B., Divate, A.D. 2013. Physical and sensory characteristics of Ready-To-Eat food prepared from finger millet based composite mixer by extrusion. Agric. Eng. Int. CIGR J., 15: 101-105.

\section{How to cite this article:}

Patekar, S.D., D.R. More and Satwadhar, P.N. 2017. Studies on Preparation and Nutritional Quality of Sorghum-Fingermillet Chakli. Int.J.Curr.Microbiol.App.Sci. 6(7): 1381-1389. doi: https://doi.org/10.20546/ijcmas.2017.607.165 